\title{
An Evaluation of a Nutritional Educational Proramme for Obese Children
}

\author{
Norimah Said*, Rasidah Mohamed \\ Nursing Department, Faculty of Health Sciences, \\ Universiti Teknologi MARA Selangor, Bandar Puncak Alam, Selangor, Malaysia \\ norimah2809@puncakalam.uitm.edu.my
}

\begin{abstract}
Overweightness and obesity is a problem that has been rising in the Malaysian suburban environment. This study is conducted to evaluate the healthy food behavior, attitudes, knowledge and healthy environment of obese school children aged 10-11 years old. Obese school children received the nutritional educational program (NEP) comprised of a video, a comic reading session and a food selection game. The intervention resulted in a significant increase for healthy food behaviour, attitude and knowledge. However, there is an only minimal impact for a healthy environment. Overall, the results indicate that the nutritional educational program has positive impact in preventing obesity.
\end{abstract}

Keywords: obesity; healthy food behavior; knowledge; nutritional educational program (NEP)

eISSN 2398-4279 @ 2018 . The Authors. Published for AMER ABRA cE-Bs by e-International Publishing House, Ltd., UK. This is an open access article under the CC BY-NC-ND license (http://creativecommons.org/licenses/bync-nd/4.0/). Peer-review under responsibility of AMER (Association of Malaysian Environment-Behaviour Researchers), ABRA (Association of Behavioural Researchers on Asians) and cE-Bs (Centre for EnvironmentBehaviour Studies), Faculty of Architecture, Planning \& Surveying, Universiti Teknologi MARA, Malaysia.

DOI: https://doi.org/10.21834/ajqol.v3i12.136 


\subsection{Introduction}

Obesity could be caused due to a variety of environmental factors, genetic predisposition, and human behaviour. In relation to overweightness and obesity during childhood, their adulthood also will become susceptible to obesity (Kitzinger \& Karle, 2013). Obesity has been a public health problem which requires preventive measures and further treatment (Sharifah, 2011). To reduce childhood obesity, preventive action needs to take high priority. The prevention of obesity among school children in suburban and rural areas are necessary and a program in nutrition education, personal weight reduction and perceived body image need to be considered (Danis, Bahar, Isa, \& Adilin, 2014). Although, most of the children reveal that they consume two servings of fruit and two/three servings of vegetables, this is not enough to supply the needed nutrition and vitamins for the children. This shows that the program needs to educate and change obese school children's behaviour and get them to consume natural foods, vegetables, fruits instead of fast food and sweets (Roman, 2014).

Consuming a balanced diet is important because it results in academic success as well as physiological development among school children (Erturguta \& Erturgut, 2010). A research by Scaglioni, Salvioni, \& Galimberti, (2008) identified that excessive control to what and how much children eat could contribute to childhood overweightness and children's eating behaviour especially in relation to the mother. This is because they spend a lot of time together rather than the father (Scaglioni et al Salvioni, 2008). Other factors such as family and environment also influence the development of childhood obesity (Serene, Shamarina, \& Mohd, 2011).

The prevalence of child obesity is increasing rapidly in Malaysia and this trend should be closely monitored. For this reason, a study was carried out in 2013 among school children in primary four and six between the ages of ten to twelve years old in Puncak Alam who had a risk of obesity. Data showed that $54.9 \%$ of the respondents were overweight, while $45.1 \%$ of the respondents were pre-obese and obese from a total of 150 samples (unpublished material, 2013). Another screening on BMI was carried out in 2014 with data showing that $58.2 \%$ out of 287 school children were identified as overweight and obese. This data showed an increasing figure as compared to childhood overweightness and obesity being $16.3 \%$ in the year 2005, and $21.8 \%$ in year 2006 in Selangor

A study by Ruzita \& Wan. Azdie, (2007) found that children in urban area are more exposed to nutritional information while possessing self-motivation compared to children in suburban and rural areas. However, none of the intervention programme has been done in a suburban area. This justifies the need for the intervention programme to be conducted in a suburban area using an interactive health educational programme as compared to the more common approach of using flex charts and cooking demonstrations since school children will learn better when there is interactive learning.

\subsection{Literature Review}

Nutritional education is health education on nutrition to increase children's awareness on the selection of healthy foods. It have been needed to enhance basic understanding of needs for carbohydrates, proteins, and fats, minerals and calcium in food (Contento, 2011). The 
concern on nutritional adequacy and purpose of the food guides are important to ensure school children eat the right food in sufficient quantity to provide all the nutrients needed for growth and health; as well as to avoid overweight and obesity.

Specifically, the implementation of nutritional educational programme among obese school children has been important to promote knowledge on nutritious and healthy eating. Studies showed that obese children consumed more food containing excessive fat and less fruit and vegetables as recommended by the food guide pyramid adopted by the US Department of Food and Agriculture in the Department of Health and Human Services (Garipağaoğlu et al., 2008). A comprehensive evaluation for obesity prevention and intervention has been needed.

\subsection{Methodology}

\subsection{Study area}

The study was carried out in Puncak Alam which is a developing suburban area with all the amenities of a township including easy access to fast food and supermarkets.

\subsection{Study subject and sample selection.}

An experimental study was conducted among primary schools. Cluster sampling was used in this study. The self-administered questionnaires and 24 hour dietary recall were distributed to the school children and answered with parents. The sample size was determined based on Krejcie and Morgan's table (1970). A total of 287 school children were screened to determine their body mass index (BMI) percentile and 165 were identified as overweight and obese. However, only 103 school children were willing to be involved in this NEP after permission was obtained from their parents.

\subsection{Data collection}

A structured questionnaire was adapted from Wilson, Magarey, \& Mastersson (2008) to evaluate the food behaviours, attitudes, environments and knowledge associated with healthy eating. The identified students were given a pre- and post-intervention questionnaire. Each individual item of the questionnaire contributed to one group score and response for each item (Wilson et al., 2008).

\subsection{Children's Anthropometric measurements}

All anthropometric measurement was carried out with the teachers as assistants. The teachers were trained before the measurement steps were taken by the researcher. The measurement was taken twice and the mean was calculated. If the difference between two measurements was more than $10 \%$, a third measurement was taken and the median was used. Body weight was measured with a SECA Digital weighing scale Model 803 (SECA) to the nearest $0.1 \mathrm{~kg}$ while height was measured with a portable SECA stadiometer Model 213 (SECA) to the nearest $0.1 \mathrm{~cm}$. BMI was calculated by using the Child and Teen BMI Calculator 
to determine the BMI percentile. Anthropometric status was classified using the CDC BMIfor-age growth charts for girls and boys taking into account these differences and allowing for translation of BMI number into percentile for a child's or teen's sex and age.

\subsection{Nurtitional Educational Programme (NEP)}

This programme was structured and adopted from a study by Ruzita \& Wan Azdie (2007) and developed used a psycho educational intervention method based on Kolb's Model of Learning Styles and Experiential Learning. The video with content on 'Food Pyramid', 'Fruits and vegetables' and 'Body Mass Index' was used with permission obtained from the Department of Health Promotion, Ministry of Health. The comic "Kembara Alam Sam" from the Nutrition Month Malaysia, Nutrition Society of Malaysia (NMM) 2010 was presented afterwards.

\subsection{Findings}

\subsection{Healthy food behaviour}

The result shows the frequency for healthy food behaviour. The percentage of healthy eating behaviour for overweight and obese school children before the NEP was $78(98.7 \%)$ respondents followed by $1(1.3 \%)$ having poor eating behaviour. However, following the NEP, $79(100 \%)$ or all of the respondents have a healthy eating behaviour. This result indicates a significant increase where the only student $(1.3 \%)$ with poor eating behaviour becomes zero post nutritional educational programme (Table 1).

\subsection{Attitude on fruits and vegetables}

Nine items were used to evaluate respondents' attitude in relation to fruits and vegetables. The findings are presented in Table 2. From the table, it can be seen that none of the respondents $(0 \%)$ shows a healthy attitude in relation to fruits at pre-test. During the posttest, only $2(2.5 \%)$ of the respondents showed any improvement in their healthy attitude to fruits. Those with poorer attitude to fruits and needed to be observed were $79(100 \%)$ for pretest but was reduced during the post-test to $77(97.5 \%)$. This result indicates the NEP has increased the percentage of respondents' attitude to consume fruits by $2.5 \%$.

The result of attitude in relation to vegetable consumption shows $2(2.5 \%)$ respondents to have a healthy attitude followed by $77(97.5 \%)$ with poor attitude and needed to be observed during the pre-test. However, during the post intervention programme the attitude related to vegetables consumption increased to $4(5.1 \%)$. Those with poor attitude and need to be observed decreased to $75(94.9 \%)$ in the post-test.

\subsection{Healthy environment selection of fruits and vegetables}

The category for environment contained eight items in order to assess the healthy environment selection of fruits and vegetables. The findings are presented in Table 3. Respondents with a healthy environment selection of fruits and vegetables were $5(6.3 \%)$ for the pre-test while $74(93.7 \%)$ had poor environment and needed to be observed. Post-test 
results showed $2(2.53 \%)$ respondents to have a healthier environment selection of fruits and vegetables as compared to poor environment $77(97.5 \%)$ respondents. These results indicate that the NEP has only minimal impact in relation to healthy environment on selection of fruits and vegetables

Table 1. Frequency for healthy food behaviour

\begin{tabular}{lllll}
\hline $\begin{array}{l}\text { Healthy food behaviour } \\
\geq 18 \text { healthy value }\end{array}$ & Pre test & Percentage & Post test & Percentage \\
$\leq 18$ range to observed & & & & \\
\hline Healthy eating behaviour & 78 & 98.7 & 79 & 100 \\
Poor eating behaviour & 1 & 1.3 & 0 & 0 \\
\hline
\end{tabular}

Table 2. Frequency for attitude

\begin{tabular}{|c|c|c|c|c|}
\hline $\begin{array}{l}\text { Healthy frequency } \\
\geq 16 \text { healthy value } \\
\leq 16 \text { range to be observed }\end{array}$ & Pre-test & percentage & \multicolumn{2}{|c|}{ Post-test } \\
\hline Fruits & & & & \\
\hline $\begin{array}{l}\text { Healthy attitude } \\
\text { Poor attitude and need to be } \\
\text { observed } \\
\quad \text { Vegetables }\end{array}$ & $\begin{array}{l}0 \\
79\end{array}$ & $\begin{array}{l}0 \\
100\end{array}$ & $\begin{array}{l}2 \\
77\end{array}$ & $\begin{array}{l}2.5 \\
97.5\end{array}$ \\
\hline Healthy attitude & 2 & 2.5 & 4 & 5.1 \\
\hline $\begin{array}{l}\text { Poor attitude and need to be } \\
\text { observed }\end{array}$ & 77 & 97.5 & 75 & 94.9 \\
\hline
\end{tabular}

\subsection{Knowledge on fruits and vegetables}

Nutritional knowledge was evaluated based on the respondents' knowledge on fruits and vegetables. The results are portrayed in Table 4. Respondents' with good knowledge on vegetables for the pre-intervention programmes were $40(50.6 \%)$ followed by $39(49.4 \%)$ respondents with poor knowledge. However, following the post-intervention programme, the respondents with good knowledge on vegetables increased to $69(87.4 \%)$ while $10(12.6 \%)$ respondents still had poor knowledge on vegetables and needed to be observed. Respondents with good knowledge on fruits pre-intervention programme were $9(11.4 \%)$ while $70(88.6 \%)$ respondents had poor knowledge. However, the post-intervention programme showed an increased to $63(79.7 \%)$ respondents with good knowledge on fruits as compared to poor knowledge at $16(20.3 \%)$ respondents. These results indicate that the NEP has a significant impact on the school children's knowledge on fruits and vegetables.

Table 3. Frequency for environments selection of fruit and vegetables

\begin{tabular}{llccc}
\hline $\begin{array}{l}\text { Healthy environment } \\
\geq 19 \text { healthy value } \\
\leq 19 \text { range to observed }\end{array}$ & Pre test & Percentage & Post test & Percentage \\
\hline \multicolumn{1}{c}{ Environment } & & & & \\
$\begin{array}{l}\text { Healthy environment selection } \\
\text { fruits and vegetables }\end{array}$ & 5 & 6.3 & 2 & 2.53 \\
$\begin{array}{l}\text { Poor environment and need to } \\
\text { be observed }\end{array}$ & 74 & 93.7 & 77 & 97.5 \\
\hline
\end{tabular}


Table 4. Frequency for knowledge on fruits and vegetables

\begin{tabular}{|c|c|c|c|c|}
\hline Healthy value & $\begin{array}{l}\text { Pre } \\
\text { Test }\end{array}$ & Percentage & $\begin{array}{l}\text { Post } \\
\text { Test }\end{array}$ & Percentage \\
\hline \multicolumn{5}{|c|}{ Vegetables 3-value good knowledge and $<3$ poorer knowledge and need to observe } \\
\hline $\begin{array}{l}\text { Good } \\
\text { knowledge }\end{array}$ & 40 & 50.6 & 69 & 87.4 \\
\hline $\begin{array}{l}\text { Poorer } \\
\text { knowledge }\end{array}$ & 39 & 49.4 & 10 & 12.6 \\
\hline \multicolumn{5}{|c|}{ Fruits- 2 value good knowledge and $<2$ poorer knowledge and need to observe } \\
\hline $\begin{array}{l}\text { Good } \\
\text { knowledge }\end{array}$ & 9 & 11.4 & 63 & 79.7 \\
\hline $\begin{array}{l}\text { Poorer } \\
\text { knowledge }\end{array}$ & 70 & 88.6 & 16 & 20.3 \\
\hline
\end{tabular}

\subsection{DISCUSSION}

\subsection{Healthy food behaviour}

This study shows a $100 \%$ increase in healthy food behaviour during the post-test. This finding indicates that there is an increase in healthy food behaviour in the post-intervention programme compared to pre-intervention but it also showed that overweight and obese school children who have knowledge and healthy food behaviour still need practice them in their daily lives after the intervention programme. This finding also demonstrates that overweight and obese school children have knowledge in choosing the 'best' or right food behaviour in their dietary patterns. This may be influenced by their parents, peers, and environment. In addition, the usage of educational media such as comics and videos in this NEP may be capable to attract overweight and obese school children to give more attention in learning and understanding the food pyramid and a balanced diet. Games on selecting healthy food enable the children to develop decision making skills in selecting healthy food without being influenced by parents, and peers. This finding is supported by a previous study by Başkale \& Bahar, (2011) which found that nutrition educations increased score nutrition knowledge and nutrition behaviour where the experimental group between pre-test and posttest 1 was significant; and pre-test and post-test 2 was also significant $(p-<.001)$. Demirozu, Pehlivan, \& Camliguney (2012) suggested that in order to influence the knowledge and healthy food behaviour of obese school children, nutrition education must be done through multiple channels such as in the school, parents and media..

\subsection{Attitude towards fruits and vegetables}

The results indicate that the overweight and obese school children had a significant increase in positive attitude towards fruits during the post-test, hence decreasing the attitudes that need to be observed. The attitude on vegetables' consumption has also shown a significant increase in post-intervention. Ranges that need to be observed decreased after the intervention programme. Overall, these results indicate that the NEP conducted in this study helped to enhance the attitude towards consumption of fruit and vegetables by overweight 
and obese school children. This result agrees with findings by Preplip et. al (2011) which showed significant changes in teacher influence on attitude towards consumption of fruits and vegetables for pre- and post-test in the intervention school. A previous study on nutrition education has shown the nutritious attitude score among the intervention group of children in rural areas to be higher as compared to urban areas (Ruzita At, Wan Azdie MAB,2007).

\subsection{Environment selection of fruits and vegetables}

The results indicate that NEP has only a minimal impact in relation to healthy environment between pre- and post-intervention. . These may be due to environmental factors of overweight and obese school children such as parents, peers, home environment, hawkers, media, economic factor and school canteen which influence the environment selection of food especially fruits and vegetables.

Binkiewicz-Glińska et al. (2012) found that school children were more likely to buy rice, sweet biscuits, and junk food compared to buying fruits and vegetables. Marketing strategies were also in place to maximise sales of unhealthy products. Furthermore, the factor of television food advertisements may influence food consumption among school children. These media may contribute to the development of child and adolescent obesity where screen time advertising of junk food and fast food increases children's requests for those particular foods and products (Strasburger, 2011).

Maternal influence was also a predicator environmental influence on dietary pattern of fruits consumption and vegetables consumption among school children. This may be due to mothers having a greater degree of control over their child's food intake and influence their daughters' weight and eating habits, hence placing daughters at risk for developing problematic eating behaviours (Scaglioni et al., 2008). The mothers with a higher level of nutritional knowledge feed their children more vegetable, fruit, legumes, and less sugared drinks. They also knew to avoid giving food that contained artificial flavouring and believes in the effects of nutrition to health as compared to mothers who had a lower level of nutritional knowledge. These mothers affect children's eating habits (Yabancı, Kısaç, \& Karakuş, 2014). Another factor that contributed to parents going out to fast food restaurants such as Mc Donalds and KFC is due to these settings offering playground facilities for their children that might contribute more to children's request of fast food. Moreover, working parents tend to eat out more due to having less time to cook at home (Abdullah, Mokhtar, Bakar, \& AlKubaisy, 2015).

The home environment has the potential to affect the overweight and obese children's energy balance and diet composition since parents act as a role model for their children and may influence the family environment by exposing family members to certain foods, by actively encouraging the family members to eat certain foods, or by passively allowing certain foods in the regular diets (Golan \& Crow, 2004). Overcoming this problem by following mothers to the wet market, the obese school children can develop their confidence level when they repeatedly practice the knowledge and skills that they attained from mothers while buying healthy ingredients (Sharif, Nor, Zahari, \& Muhammad, 2015).

\subsection{Knowledge on vegetables and fruits}


The result for good knowledge on vegetables shows an increase among the overweight and obese school children where they have better knowledge on vegetables after the intervention programme. The number of respondents with poor knowledge on vegetables decreased after the post-intervention. The same can be said for the results of good knowledge on fruits, which saw an increase after the intervention programme and poor knowledge on fruits decreasing after the intervention programme. The result indicates that the NEP has a significant increase to the knowledge of vegetables and fruits among overweight and obese children.

Overall, these results indicate that the NEP has significant influence before and after the nutritional educational on dietary pattern, healthy behaviour, attitude, environment, and knowledge among overweight and obese school children except environment. These proved that effective intervention should be focused on the dietary factor because inappropriate dietary habits lead to overweightness and obesity among school children (Baskova, Baska, \& Banovcinova, 2014). These findings were supported by a systematic review of 55 previous studies which mostly targeted children aged 6-12 years old. These included 37 studies of 27,946 children and demonstrated that the programs were effective in providing awareness towards the prevention of obesity among children (Waters et al., 2013).

\subsection{Conclusion}

NEP could improve and promotes positive changes in the dietary pattern among overweight and obese school children especially in the consumption of food and healthy food behaviour, attitude, environment, and nutrition knowledge. The NEP could be implemented in Malaysia as part of the schools' health activities promotional programme and nutritional education to overcome the current rise of obesity. In the future, these nutritionals educational programmes are needed more time to implement for evaluate the impact towards healthy food behaviours and should combine physical activities are also important to enhance the knowledge on healthy nutrition and BMI.

\section{Acknowledgement}

The author wishes to thanks the Grant Lestari funding 600-IRMI/MyRA5/3/Lestari (8/2016) funding by Universiti Teknologi Mara, UiTM, Department of Health Promotion, Ministry of Health, Nutrition Month Malaysia, Nutrition Society of Malaysia, Ministry of Education and Faculty of Health Sciences, UiTM and all students who participated in this study.

\section{References}

Abdullah, N. N., Mokhtar, M. M., Bakar, M. H. A., \& Al-Kubaisy, W. (2015). Trend on Fast Food Consumption in Relation to Obesity among Selangor Urban Community. Procedia - Social and Behavioral Sciences, 202(December 2014), 505-513. doi:http://dx.doi.org/10.1016/j.sbspro.2015.08.189 
Akar, \& Sanlier, N. (2011). Compliance with Mediterranean Diet Quality Index ( KIDMED) and nutrition knowledge levels in adolescents . A case study from Turkey. Appetite, 57(1), 272-277.

Başkale, H., \& Bahar, Z. (2011). Outcomes of nutrition knowledge and healthy food choices in 5- to 6-year-old children who received a nutrition intervention based on Piaget's theory. Journal for Specialists in Pediatric Nursing, 16(4), 263-279. doi:10.1111/j.1744-6155.2011.00300.x

Baskova, M., Baska, T., \& Banovcinova, L. (2014). Selected Aspects of Dietary Habits in School-aged Youth in the Slovak Republic. Procedia - Social and Behavioral Sciences, 132, 129-134. doi:10.1016/j.sbspro.2014.04.288

Binkiewicz-Glińska, A., Bakuła, S., Kusiak-Kaczmarek, M., Kowalski, I. M., Zaborowska-Sapeta, K., ProtasiewiczFałdowska, H., ... Białkowska, M. (2012). Obesity prevention in children and adolescents - Current recommendations. Polish Annals of Medicine, 19(2), 158-162. doi:10.1016/j.poamed.2012.07.003

Contento, I. R. (2011). Nutrition education. In Nutrition Education (2nd Edition., p. 9). United States of Amerika.

Danis, A., Bahar, N. M., Isa, K. A. M., \& Adilin, H. (2014). Body Image Perspectives among Obese Adolescents in Rural Environment Setting. Procedia - Social and Behavioral Sciences, 153, 436-442. doi:10.1016/j.sbspro.2014.10.077

Demirozu, B. E., Pehlivan, A., \& Camliguney, A. F. (2012). Nutrition Knowledge and Behaviours of Children Aged 8-12 Who Attend Sport Schools. Procedia - Social and Behavioral Sciences, 46, 4713-4717. doi:10.1016/j.sbspro.2012.06.324

Etelson, Brand, Patrick, \& Shirali, A. (2003). Childhood obesity: do parents recognize this health risk? Obesity Research, 11(11), 1362-8.

Erturgut, P., \& Erturgut, R. (2010). An analysis of nutrition level of adolescent school children with respect to the educational levels and child-raising attitudes of their parents. Procedia - Social and Behavioral Sciences, 2(2), 12381243. doi:10.1016/j.sbspro.2010.03.180

Firouzi, S., Poh, B. K., Ismail, M. N., \& Sadeghilar, A. (2014). Sleep habits, food intake, and physical activity levels in normal and overweight and obese Malaysian children. Obesity Research Clinical Practise, 8, e1-e114.

Francis, M., Nichols, S. S. D., \& Dalrymple, N. (2010). The effects of a school-based intervention programme on dietary intakes and physical activity among primary-school children in Trinidad and Tobago. Public Health Nutrition, 13(5), 738-747.

Garipağaoğlu, M., Sahip, Y., Budak, N., Akdikmen, O., Altan, T., \& Baban, M. (2008). Food types in the diet and the nutrient intake of obese and non-obese children. Journal of Clinical Research in Pediatric Endocrinology, 1, 21-29.

Kain J, Uauy R, Vio F, Albala C. (2004). Trends in overweight and obesity prevalence in Chilean children: comparison of three definitions. European Journal Clinical Nutrient.Mar;56(3):200-4.

Keyte, J., Harris, S., Margetts, B., Robinson, S., \& Baird, J. (2012). Engagement with the National Healthy Schools Programme is associated with higher fruit and vegetable consumption in primary school children. Journal of Human Nutrition and Dietetics, 25(2), 155-160.

Ma, J., Wang, Z., Song, Y., Hu, P., \& Zhang, B. (2010). BMl percentile curves for Chinese children aged 7-18 years, in comparison with the WHO and the US Centers for Disease Control and Prevention references. Public Health Nutrition, 13, 1990-1996. 
Micheal Preplip, Wendelin Slusser, Chan L.Thai, Janni Kinsler, J. T. E. (2011). Effects of a School-Based Nutrition Program Diffused Throughout a Large Urban Community on Attitudes, Beliefs , and Behaviors Related to Fruit and Vegetable, 81(9).

Muckelbauer, R., Libuda, L., Clausen, K., Toschke, A. M., Reinehr, T., \& Kersting, M. (2009). Promotion and provision of drinking water in schools for overweight prevention: randomized, controlled cluster trial. Pediatrics, 123(4), e661-e667.

Norimah AK, Ruzita AT, Poh BK, Nurunnajiha N, Wong JE, Raduan S \& Ismail MN (2009). Food habits and physical activity pattern among primary school children in Malaysia. Conference Paper. Nutrition Society of Malaysia. 24 th Scientific Conference, p 38.

Poh, B. K., Ng, B. K., Siti Haslinda, M. D., Nik Shanita, S., Wong, J. E., Budin, S. B., Norimah, A. K. (2013). Nutritional status and dietary intakes of children aged 6 months to 12 years: findings of the Nutrition Survey of Malaysian Children (SEANUTS Malaysia). The British Journal of Nutrition, 110 Suppl , S21-35.

Riesch, S. K., Lyles, A., Perez, O., Brown, R. L., Kotula, K., \& Sass-Deruyter, S. M. (2005). Modifiable family factors among treatment-seeking families of children with high body mass index: report of a pilot study. Journal of Pediatric Health Care : Official Publication of National Association of Pediatric Nurse Associates \& Practitioners, 27(4), 25466.

Roman, I. (2014). The Psychology of Nutritional Behaviour and Children's Nutrition Education. Procedia - Social and Behavioral Sciences, 149, 819-824. doi:10.1016/j.sbspro.2014.08.327

Ruzita AT, Wan Azdie MAB, I. M. (2007). The Effectiveness of NEP for Primary School Children, 13(1), 45-54.

Scaglioni, S., Salvioni, M., \& Galimberti, C. (2008). Influence of parental attitudes in the development of children eating behaviour. The British Journal of Nutrition, 99 Suppl 1, S22-5. doi:10.1017/S0007114508892471

Serene, T. E. H., Shamarina, S., \& Mohd, N. M. T. (2011). Familial and socio-environmental predictors of overweight and obesity among primary school children in Selangor and Kuala Lumpur. Malaysian Journal of Nutrition, 17(2), 151-62. Retrieved from http://www.ncbi.nlm.nih.gov/pubmed/22303570

Sharif, M. S. M., Nor, N. M., Zahari, M. S. M., \& Muhammad, R. (2015). Following Mothers to the Wet Market: The Significant Benefits Gain by Young Generations. Procedia - Social and Behavioral Sciences, 170(0), 197-205. doi:http://dx.doi.org/10.1016/j.sbspro.2015.01.029

Sumarni Mohd, G., Muhammad Amir, K., Ibrahim Md, S., Mohd Rodi, I., Izzuna Mudla, M. G., \& Nurziyana, I. (2006). Obesity among schoolchildren in Kuala Selangor: a cross-sectional study. Tropical Biomedicine, 23(2), 148-54. Retrieved from http://www.ncbi.nlm.nih.gov/pubmed/17322816

Wilson, A. M., Magarey, A. M., \& Mastersson, N. (2008). Reliability and relative validity of a child nutrition questionnaire to simultaneously assess dietary patterns associated with positive energy balance and food behaviours, attitudes, knowledge and environments associated with healthy eating. International of Behavioral Nutrition and Physical, 12, 1-12. doi:10.1186/1479-Received

Yabancı, N., Kısaç, I.., \& Karakuş, S. Ş. (2014). The Effects of Mother's Nutritional Knowledge on Attitudes and Behaviors of Children about Nutrition. Procedia - Social and Behavioral Sciences, 116, 4477-4481. doi:10.1016/j.sbspro.2014.01.970 